UDC: 632.937 .12

\title{
BIOECOLOGICAL PECULIARITIES AND ECONOMIC SIGNIFICANCE \\ OF LARGE FRUIT BARK BEETLE (SCOLYTUS MALI BECHSTEIN, 1805) \\ AND FIG BARK BEETLE (HYPOBORUS FICUS ERICHSON, 1836) IN THE SOUTHERN SLOPES OF THE GREAT CAUCASUS (AZERBAIJAN)
}

\author{
K. B. Isayeva \\ Institute of Zoology, Azerbaijan National Academy of Sciences \\ A. Abbaszadeh St., 1128 side street, 504 block, Baku, Az 1073, Azerbaijan \\ Corresponding author e-mail: kemale.behlulqizi@mail.ru
}

Isayeva K.B. Bioecological peculiarities and economic significance of large fruit bark beetle (ScoIytus mali Bechstein, 1805) and fig bark beetle (Hypoborus ficus Erichson, 1836) in the southern slopes of the Great Caucasus (Azerbaijan). Studia Biologica, 2021; 15(1): 61-66 • DOI: https:// doi.org/10.30970/sbi.1501.641

Background. Bark beetles (Coleoptera, Curculionidae, Scolytinae) are major pests of wood-fruit trees, and infestations often accelerate tree death. Bark beetles are insects that are closely related to their host trees. According to the type of feeding they belong to xylophages [7]. They prefer weakened, sick or damaged trees. Thus, bark beeteles can more easily penetrate into trees affected by various natural phenomena (wind, storm, rain) or primary pests. They are hardly ever found in rotting trees.

The research was carried out on the southern slopes of the Great Caucasus during the period 2013-2016. The great difference in the altitude in the study area results in a variety of natural conditions. This, in turn, leads to the richess of fauna and flora of the area. Thus, valuable fruit trees grow both in the forests and fruit farms of the study region. However, large numbers of fruit trees are attacked by bark beetles every year, which negatively affects the numbers and the quality of trees. Untimely processing of the trees leads to their drying and destruction.

According to modern systematics, bark beetles belong to the Scolytinae (Latreille, 1804 ) subfamily of the Curculionidae (Latreille, 1802) family. There are about 6,000 species of bark beetles from 28 triba and 230 genera in the world [8]. These insects also cause serious damage in countries neighboring of Azerbaijan [1, 2, 9, 11]. Despite the fact that bark beetles are of great agricultural importance, they are not sufficiently studied in Azerbaijan.

( 2021 K. В. Isayeva. Published by the Ivan Franko National University of Lviv on behalf of Біологічні Студії / Studia Biologica. This is an Open Access article distributed under the terms of the Creative Commons Attribution License (http://www.budapestopenaccessinitiative.org and Creative Commons Attribution 4.0 License), which permits unrestricted reuse, distribution, and reproduction in any medium, provided the original work is properly cited.

ISSN 1996-4536 (print) • ISSN 2311-0783 (on-line) • Біологічні Студії / Studia Biologica • 2021 • Том 15 / № 1 • С. 61-66 
Materials and Methods. The material for research was collected and treated according to common entomological methods. The vegetative organs of various trees were cut and dissected to detect adult beetles, eggs and larvae of bark beetles. Identification of bark beetles was carried out according to keys. MBS-9 microscope was used to determine the morphological features of beetles.

Results. As a results of the research, we analyzed 241 samples (237 adults and 4 pupae) of bark beetles collected in 7 districts of the southern slopes of the Greater Caucasus, of which 54 specimens belonged to Scolytus mali and 187 to Hypoborus ficus.

Conclusion. Out of 30 species of bark beetles detected on the southern slopes of the Greater Caucasus, 7 ones (Scolytus mali Bechst., S. amygdali Guer., S. fasciatus Rtt., S. rugulosus Ratz., Hypoborus ficus Er., Xyleborus dispar F., X. saxeseni Ratz.) were determined as fruit trees pests. Two of them (Scolytus mali and Hypoborus ficus) are widely distributed in the area and cause serious damage to fruit trees.

Keywords: bark beetle, larva, pupae, Great Caucasus, Azerbaijan

\section{INTRODUCTION}

The relief of the Great Caucasus is divided into highlands and foothills. The big difference in altitude created preconditions for rich biodiversity of fauna and flora. Valuable fruit trees grow in the regions of the studied area. The fruit trees occupy one of the important places in the economy of the Azerbaijan Republic. However, many fruit trees severely suffer from bark beetles.

In spite of the fact that bark beetles are major pests of fruit-wood plants, they were not studied in detail in Azerbaijan. The first information about bark beetles of Azerbaijan can be found in the book of N. H. Samedov "Fauna and biology of beetles damage the agricultural plants in Azerbaijan". He registered 11 species of bark beetles for the fauna of Azerbaijan, of which 9 were found on the southern slopes of the Greater Caucasus [10]. As a result of our research, 30 species of bark beetles of 15 genera [5] were recorded for the first time on the southern slopes of the Greater Caucasus. Seven species (Scolytus mali Bechst., S. amygdali Guer., S. fasciatus Rtt., S. rugulosus Ratz., Hypoborus ficus Er., Xyleborus dispar F., X. saxeseni Ratz.) were identified as major pests of fruit trees. Moreover, $S$. mali was found in the Gakh and Ismayilli districts for the first time, as well as $H$. ficus in the areas of Balaken, Gakh, Ismayilli and Gabala. It was found that Scolytus mali and Hypoborus ficus are particularly widespread in the area under study, causing serious damage to fruit trees.

The paper presents information about two species of bark beetles (Scolytus mali Bechst., Hypoborus ficus Er.) which are widespread and attack fruit trees in the southern slopes of the Great Caucasus.

\section{MATERIALS AND METHODS}

The materials for the research were collected and treated according to common entomological methods $[3,4,12]$. The vegetative organs of various trees were cut and dissected to detect adult beetles, eggs and larvae of bark beetles. Sawn branches of trees were placed in linen bags, which were 10-15 cm longer than the branches to prevent bark beetles from leaving the bags. The bags were provided with labels containing the name of the tree, the place and date of collection, and some other data on environmental

ISSN 1996-4536 (print) • ISSN 2311-0783 (on-line) • Біологічні Студії / Studia Biologica • 2021 • Том 15 / № 1 • C. 61 -66 
conditions. During laboratory processing, adult beetles, pupae, and sometimes larvae and eggs were removed from under the bark by a soft brush. Collected materials were placed into glass tubes containing $70-75 \%$ alcohol. The glass tubes were provided with labels containing information about the place, data of sampling, and the state of the tree during the collection of materials. In order to identify the wintering place of beetles the tree bark, litter and the upper layers of the ground were examined carefully. Bioecological peculiarities and phenology of bark beetles were studied.

Identification of bark beetles was carried out according to special keys [6]. MBS-9 microscope was used to determine the morphological features of the beetles.

\section{RESULTS AND DISCUSSION}

Out of 30 species of bark beetles recorded on the southern slopes of the Greater Caucasus, 7 ones (Scolytus mali Bechst., S. amygdali Guer., S. fasciatus Rtt., S. rugulosus Ratz., Hypoborus ficus Er., Xyleborus dispar F., X. saxeseni Ratz.) were determined as fruit trees pests. Two of them (Scolytus mali and Hypoborus ficus) are widely distributed in the area and cause serious damage to fruit trees.

\section{Genus: Scolytus Geoffroy, 1762}

\section{Scolytus mali Bechstein, 1805 - large fruit bark beetle}

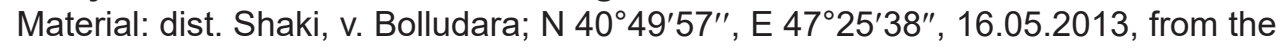
apple tree, 11 ; 18.05 .2013 , from the apple tree $2 \delta 3$; $; 17.07 .2013$, from the cherry tree

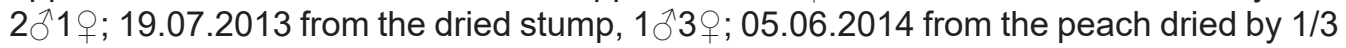
part $2 \hat{\gamma} ; 08.06 .2014$ from the same tree $1 \hat{\jmath} 1$ \% ; 30.05.2015 from the plum 1 ; ; 01.06.2015, under the bark of the same plum $3{ }^{\lambda} 2 \circ ; 05.07 .2016$ on roadside cherries $2 \hat{\jmath} 4$.

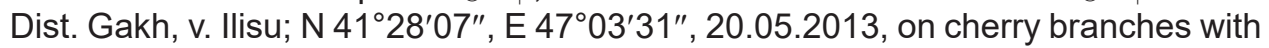
a diameter of $9 \mathrm{~cm}, 3 \hat{1}$; $; 21.07 .2013$ on the other branch of the same cherry tree, $2 \precsim 3$; ; on apple tree growing at $5,5 \mathrm{~m}$ distance from cherry tree, $1 \hat{\delta} ; 10.06 .2014$ on the apricot trunk at a distance of $32-33 \mathrm{~cm}$ from the surface of the earth, $133 \circ ; 07.07 .2016$ from damaged plum branches in a rural garden plot, $2+$, in the same garden from dried branches of an apple tree $1 \hat{\jmath} 1$.

Dist. Ismayilli, v. Agbulag: N 4042'35"; E 48¹3'17" - 02.02.2014, under the bark of an old peach, $2 \hat{\jmath}, 1$ pupa; 05.28.2015 from plum branches $1 \hat{\delta}, 3$ pupae.

The species damages all fruit trees, showing preference for apple and cherry trees. It is widespread in forestry and horticultural farms in Azerbaijan.

It is a typical pest for stone fruit trees in orchards. It causes serious damage to such fruit trees as apple, pear, cherry, apricot, peach, and plum trees. In the studied areas, the large fruit bark beetle was recorded on tree trunks or on branches with 22-24 cm in diameter (Fig. 1). It prefers standing or lying depressed trees.

The beetle is 3-4.5 mm long, black or reddish brown, shiny; elytra dark brown or black-brown; pronotum short, broad; abdomen straight, sloping, without teeth and tubercles.

The large fruit bark beetle hibernates in larva stage under the bark. The legless larvae of the beetle are white. In spring, the larvae that have completed their development gnaw small extensions at the end of their turn and pupate into them. Beetles gnaw exit holes and go out in mid-June. Males die after mating. The female gnaws a large hole and penetrates under the bark. The mother tunnel is $5-6 \mathrm{~cm}$ long and $2 \mathrm{~mm}$ wide. Copulation occurs in the expansion at the beginning of the egg gallery. On the sides of 
the egg gallery, the female gnaws holes where it lays eggs. Later, larvae hatch from eggs. They begin to gnaw their own larval holes. The tunnels made by the larvae are densely arranged and have a straight shape. At the end of the development stage, larvae make holes for hibernating.

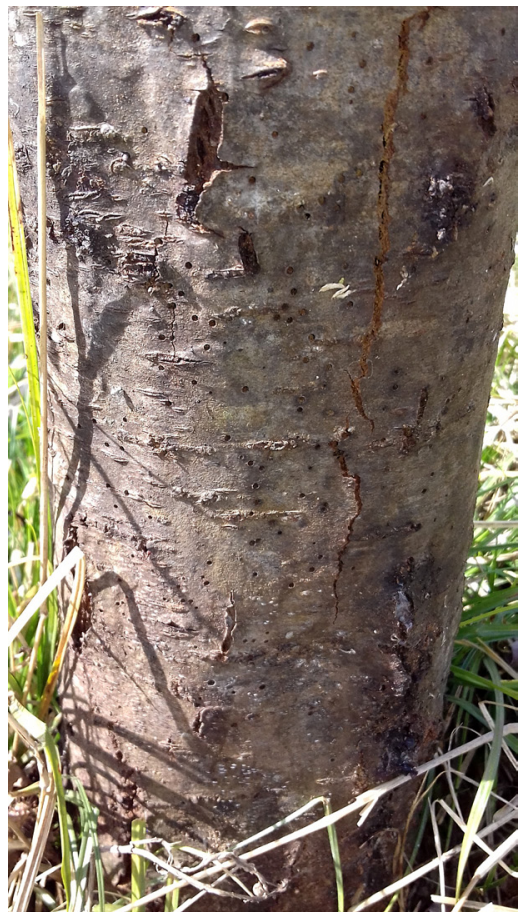

Fig. 1. Entrance and flight holes opened by fruit tree bark beetles on a tree trunk

The beetle gives one generation in a year on the southern slopes of the Great Caucasus. The beetles were the most numerous in June. Despite the fact that in most cases beetles attack diseased trees, they were sometimes found on healthy trees too. According to our observations, more intense traces of beetles were observed on old trees than on young ones.

\section{Genus: Hypoborus Erichson, 1836 Hypoborus ficus Er. - fig bark beetle}

Material: dist. Balakan, v. Talalar, N 41 42'36", E $46^{\circ} 20^{\prime} 57^{\prime \prime}, 24.07 .2013,9$ specimens on a roadside fig tree; 17 specimens from an old fig tree growing in the orchard.

Dist. Zagatala, v. Daghly, N 4131'23", E $46^{\circ}$ 31'55", 22.07.2013 12 specimens from an old fig tree growing in the orchard, 32 specimens from tree and bush branches of 2-3 cm in diameter;

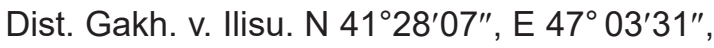
21.07.2013, 20 specimens on dried mulberry tree branch $\mathrm{d} \approx 3 \mathrm{~cm}$ in diameter, 07.07.2016, 2 species;

Dist. Shaki, v. Bolludara, N 4049'57", E $47^{\circ}$ 25'38", 19.07.2013, 13 specimens on a fig tree, 05.07.2016, 11 specimens; v. Kish, N 4115'00", E 47 11'30", 05.07.2016, 15 specimens;

Dist. Ismayilli, v. Aghbulag, N 4042'35", E 48¹3'17", 02.06.2014, 5 species; 28.05.2015, 9 specimens under the bark of a fig tree;

Dist. Gabala, v. Gamarvan, N 4103'47", E 4747'31", 03.06.2014, 29 specimen on a fig tree;

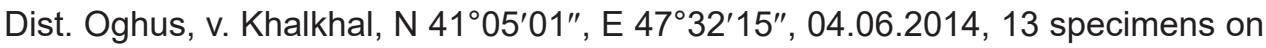
a fig tree.

It is a widespread bark beetle in all regions on the southern slopes of the Greater Caucasus that causes damage to fig trees. It also occurs on maple trees. It was found on trunks or young branches of the fig tree (Fig. 2). The beetle attacks trees that are already weakened by disease, drought, smog, overcrowding, conspecific beetles, or physical damage. This species was not detected on live trees. This is due to the fact that the juice of the fig tree is poisonous [13].

The beetles are 1-1.3 mm long, with short and broad body; their head is gray or black-brown; elytra and legs are reddish brown, antennae are yellow. The head of the beetle is short, broad, shiny and wrinkled, with a hairy forehead. Elytra short, broad.

The larvae of the fig bark beetle hibernate under the bark. Egg and larval galleries are situated in the trunk or under the bark (Fig. 3). Egg galleries are $0.5-2 \mathrm{~cm}$ long and lo- 
cated horizontally. The galleries can be widened up to $2.2 \mathrm{~mm}$ in the front of the entrance and then narrow down to $1 \mathrm{~mm}$ on both sides. The females lay about 50 eggs in small cavities on the sides of the mother tunnel. According to N.H. Samedov [10], the female of summer generation can lay about 70-80 eggs. Larvae hatch in July and bore larval galleries starting from the mother tunnel and nearly perpendicular to it. The larval galleries are short $-2 \mathrm{~cm}$ in length. At the end of the galleries, the larvae gnaw small cavities and pupate in them in August. Beetles fly out during the second ten days of August.

Fig. 2. Fig bark beetles (Hypoborus ficus) discovered in a branch of a fig tree

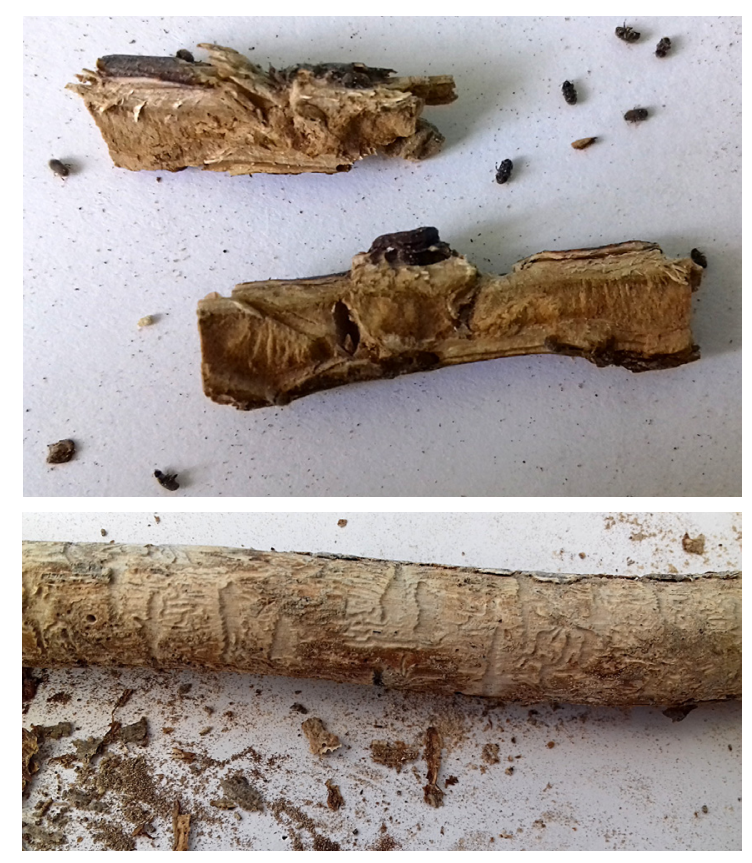

Fig. 3. Galleries of the Hypoborus ficus in the fig tree branches

According to our results, bark beetles attack fig trees more frequently after a harsh winter because the trees are weaker.

This bark beetle gives 3-4 generation during a year in France, Algeria, Israel and 2 generations in Georgia and Crimea [10]. In the studied area, it gives 1 generation in a year and the larvae of the second generation hibernate.

N.H. Samedov claims that the bark beetle is the carrier of the "fig tree cancer" pathogen, Phomopsis cinerescens spores [10].

\section{CONCLUSION}

Out of 30 species of bark beetles found by us on the southern slopes of the Greater Caucasus, 7 ones (Scolytus mali Bechst., S. amygdali Guer., S. fasciatus Rtt., S. rugulosus Ratz., Hypoborus ficus Er., Xyleborus dispar F., X. saxeseni Ratz.) were determined as fruit trees pests. Two of them (Scolytus mali and Hypoborus ficus) are widely distributed in the area and cause serious damage to fruit trees.

S. mali was found in the Gakh and Ismayilli districts for the first time, as well as $H$. ficus in the areas of Balaken, Gakh, Ismayilli and Gabala. It was found that Scolytus mali and Hypoborus ficus are particularly widespread in the area under study, causing serious damage to fruit trees. 


\section{COMPLIANCE WITH ETHICAL STANDARDS}

Conflict of Interest: The authors declare that the research was conducted in the absence of any commercial or financial relationships that could be construed as a potential conflict of interest.

Human Rights: This article does not contain any studies with human subjects performed by any of the authors.

Animal studies: All institutional, national and institutional guidelines for the care and use of laboratory animals were followed.

1. Amini S., Hosseini R., Sohani M. A faunal study of bark beetles (Coleoptera: Curculionidae: Scolytinae) in Guilan province in North of Iran. Entomofauna, 2013; 34(12): 169-176.

Google Scholar

2. Burjanadze M. Efficacy of Beauveria bassiana isolate against pine shoot beetle Tomicus piniperda L. (Coleoptera, Scolytidae) in laboratory. Bulletin of the Georgian National Academy of Sciences, 2010; 4(3): 119-122.

Google Scholar

3. Fasulati K.K. Field studying of terrestrial invertebrates. Moscow: Visshaya shkola, 1961; 304 p. (In Russian)

Google Scholar

4. Guliyeva H.F. Research methods of entomology. Baku: Zardabi LTD, 2015; 262 p. (In Azerbaijanian)

5. Isayeva K.B. To the study of the bark beetle fauna (Coleoptera, Ipidae) of the southern slopes of the Greater Caucasus. Reports of the Academy of Agricultural Sciences of Georgia, 2017; 1(37): 155-159. (In Russian)

6. Key for insects of European part of the USSR: II v., Coleoptera and Strepsiptera. Under edition of G.Ya. Bey-Bienko. M.; L.: Nauka, 1965; 668 p. (In Russian)

Google Scholar

7. Krivolutskaya G.O. Entomofauna of the Kuril Islands. Leningrad: Nauka, 1973, 315 p. (In Russian)

Google Scholar

8. Nikulina T.V. The keys for identification of bark-beetles (Coleoptera: Curculionidae: Scolytinae)

of Ukraine. Caucasian Entomological Bulletin, 2014; 10(1): 89-106.

Crossref $\bullet$ Google Scholar

9. Petrov A.V. A key to genera and species of the tribe Hylesinini Erichson, 1836 (Coleoptera: Curculionidae: Scolytinae) from Russia and adjacent countries. Russian Entomological Journal, 2018, 27(2): 179-189.

Crossref $\bullet$ Google Scholar

10. Samedov N.H. Fauna and biology of beetles damaging the agricultural plants in Azerbaijan. Baku: Publishing house AS Azerb., 1963; 383 p. (In Russian)

11. Sarikaya O., Kavaklı S. Faunistic observations on Scolytinae (Coleoptera: Curculionidae) in Afyonkarahisar region of Turkey. American Journal of Engineering Research (AJER), 2018; 7(6): 277-282.

12. Stark V.N. Instructions for collection and styding of bark-beetles (Ipidae) M.; L.: Publishing house AS USSR, 1936; 88 p. (In Russian)

13. Stark V.N. Fauna of the USSR: Coleoptera. Moscow: Publishing house AS USSR, 1952; V. XXXI, Bark-beetles, 461 p. (In Russian)

$\begin{array}{cccc}\text { Received / Одержано } & \text { Revision / Доопрацьовано } & \text { Accepted / Прийнято } & \text { Published / Опубліковано } \\ \text { 04 December, 2020 } & \text { 25 February, 2021 } & \text { 17 March, 2021 } & \text { 31 March, 2021 }\end{array}$

ISSN 1996-4536 (print) • ISSN 2311-0783 (on-line) • Біологічні Студії / Studia Biologica • 2021 • Том 15 / № 1 • C. 61-66 